\title{
ОКРЕМІ АСПЕКТИ ПРОВЕДЕННЯ МІСЦЕВИХ ВИБОРІВ В УКРАЇНІ: ПРОБЛЕМИ ТА СПОСОБИ ЇХ ВИРІШЕННЯ
}

Шульга A.A., канд. наук з держ. упр, ст. викладач, Інститут державного управління, Чорноморський національний університет імені Петра Могили, м. Миколаїв, Україна

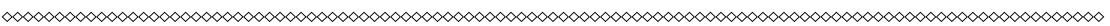

У статті аналізуються окремі правові та практичні аспекти проведення місиевих виборів в Україні, виявлено існуючі проблеми у виборчому прочесі та запропоновано способи їх вирішення. На початку дослідження окреслено сутність поняття «вибори» та «місцеві вибори», наведено різні точки зору вчених на тлумачення ичих двох понять. Основна частина статті присвячена характеристиці приниипів, на яких трунтується проведення місцевих виборів в нашій державі. Такими принципами є загальне, рівне і пряме виборче право, вільність виборів, таємність голосування, особисте голосування. У ході дослідження виявлено, щзо повна реалізація кожного із зазначених принципів на сьогоднішній день є неможливою, через недосконалість діючого виборчого законодавства, наявність військового конфлікту на сході країни й анексії Автономної Республіки Крим, низький рівень правової свідомості та освіченості окремих громадян. Узагальнено, щуо законодавче закріплення основоположних засад виборчого прочесу та їх суворе дотримання є невід 'ємною складовою частиною суспільно-політичного життя Украӥни та однією з ознак дієвості демократії на ї̈ території, а також гарантією легітимації того, кого обрала більшість та суспільного спокою і впевненості у дієвості власних дій (голосів). Коротко охарактеризовано виборчі системи, за якими проводяться вибори до органів місиевого самоврядування. Обгрунтовано, щзо перші дві виборчі системи є простими у використанні й у кінцевому підрахунку голосів за кандидатів та зрозумілими для громадськості, яка обирає свойх представників. Виявлено, щуо існуючий модифікований варіант третьої виборчої системи 
(пропориійної), руйнує основні ідеї представницької демократії, породжує специфічну конкурентну боротьбу як між різними політичними партіями, так і в середині кожної із них. У підсумку зазначено, що місиеві вибори є надважливим проявом демократії в Україні, коли публічне управління здійснюють не лише народні обраниі або державні службовиі різної категорії, а безпосередньо кожен громадянин, приходячи на вибори та роблячи свій власний свідомий вибір.

Ключові слова: вибори; місцеві вибори; принципи проведення виборів; виборчі системи; депутат.

Постановка проблеми у загальному вигляді. Сьогодні слово «вибори» $€$ чи не найбільш популярним в українському суспільстві та часто вживаним у повсякденному спілкуванні та на рівні вищих інститутів влади. I це більшою мірою не пов'язано із черговими виборами Президента України чи виборами до парламенту України та органів місцевого самоврядування. Це пов'язано із переосмисленням людей самого терміну «вибори» та надання йому іншого змістовного значення, виходячи за межі вже звичного загальноприйнятого його тлумачення. Адже на разі вибори для кожного громадянина нашої країни $\epsilon$ не просто процесом власного волевиявлення шляхом проставляння відповідної помітки у виборчому бюлетені, а реальним вибором напряму розвитку окремої територіальної громади чи всієї країни загалом, утвердженням нових змін та прийняттям відповідальності за власний свідомий вибір. Коли кожен громадянин усвідомлює, що він бере активну участь в публічному управлінні країни і від його рішення залежить подальша доля конкретної громади чи України загалом.

Аналіз досліджень і публікацій. Дослідженням окремих питань місцевих виборів в Україні займаються різні вчені, такі як: М. Ставнійчук, М. Корнієнко, О. Лавринович, В. Загорський, С. Телешун, І. Климкова, М. Остапенко, С. Пивоваров, В. Гробова, Ю. Ключковський, В. Куйбіда, Ю. Ганущак, О. Батанов, В. Погорілко, Е. Ковальчук та ін. Однак, незважаючи на значні напрацювання науковців, існує ряд невирішених теоретичних і практичних питань стосовно організації та порядку проведення виборів до органів міс- 
цевого самоврядування в нашій країні, зокрема, неоднозначність у тлумаченні основних засад виборчого права, дискусійність окремих положень діючого Закону України «Про місцеві вибори» тощо.

Формулювання цілей статті (постановка завдання). Метою цієї статті $є$ аналіз окремих правових і практичних аспектів проведення місцевих виборів в Україні, виявлення існуючих проблем у виборчому процесі та формулювання способів їх вирішення.

Виклад основного матеріалу дослідження. У широкому (філософському) розумінні вибори $є$ одним із виявів абсолютної свободи - свободи вибору. Як свого часу зазначив німецький учений Г. Маєр, «... у загальнонаціональному масштабі вибори $є$ найбільш відомим праву масовим процесом» [1, с. 297].

Словник української мови тлумачить слово «вибори» як обрання шляхом голосування депутатів у представницькі органи держави, службових осіб та ін. [4, с. 355]. Більш конкретизує це слово Оксфордський англійський словник - «процес, за допомогою якого населення вибирає індивідуума для державних посад» [26].

У юриспруденції та в науці державного управління існує безліч поглядів щодо пояснення змісту поняття «вибори». Так, наприклад, відомий теоретик-конституціоналіст В.Ф. Погорілко вибори визначає як форму безпосередньої демократії, народного волевиявлення, яка передбачає формування складу представницьких органів державної влади й органів місцевого самоврядування шляхом голосування. Водночас науковець зазначає, що виборами є спосіб формування складу: 1) колегіальних та індивідуальних структур відповідних представницьких органів державної влади і місцевого самоврядування; 2) колегіальних органів керівництва політичних партій та інших об'єднань громадян на їх з'іздах, конференціях, збоpax; 3) колегіальних та інших органів управління підприємств, установ, організацій [23, с. 174]. Подібне визначення надає польський вчений-конституціоналіст Б. Банашак, говорячи про те, що вибори є заходами, які мають на меті обрання відповідних кандидатів для виконання визначених функцій [3, с. 317]. При цьому він зазначає, що голосування $є$ частиною цілого виборчого процесу і тому поняття виборів не може бути йому тотожним [2, с. 340]. Інакше кажучи, го- 
лосування саме по собі не є виборами, а лише окремою їх частиною як процесу. Дещо розширює визначення даного поняття інший польський вчений $€$. Бучковскі, який розуміє вибори як процес, у якому беруть участь громадяни як виборці, а також політичні партії та громадські організації, які відіграють особливо важливу роль у процесі висунення кандидатів (виборчих списків) та формуванні виборчих програм, у тому числі здійсненні організованої політико-програмної діяльності у процесі проведення виборчої кампанії [5, с. 16].

Натомість російські вчені такі як І. Ільїнський, Б. Страшун та В. Ястребов визначають вибори як спосіб формування органів управління шляхом голосування осіб, які мають на це право, та прийняття рішення більшістю. На їх погляд, вибори є демократичною процедурою формування органів управління [8, с. 308]. Інший російський науковець В. Маклаков трактує вибори як процес формування державного органу влади або надання права виборній особі, реалізоване шляхом голосування уповноважених осіб за умови, що на кожну виборну посаду претендує дві чи більше особи [25, с. 318]. Ми погоджуємося із наведеними визначеннями, оскільки вони передають демократичну складову в такій публічно-управлінській категорії як вибори.

Цікаво, що вітчизняні вчені у трактуванні поняття «вибори» $\epsilon$ солідарними 3 іноземними дослідниками. Зокрема, М. Ставнійчук, вважає вибори формою безпосереднього народовладдя, яка є відображенням волі народу, способом формування конституційного складу представницьких органів державної влади та місцевого самоврядування [24, с. 7]. У свою чергу, М. Корнієнко, на наш погляд, визначає вибори доволі просто - «акт народного самоврядування» [14, с. 18]. Проте ми вважаємо, що таке визначення не розкриває всієї сутності цього поняття та його ролі у процесі здійснення публічного управління. У цьому напрямі дещо інакшим шляхом пішов О. Лавринович, який вважає, що основною ознакою демократичної влади є іiї високий рівень легітимізації, а вибори - це засіб ії отримання [15, с. 3].

Як узагальнюють Ю. Ковбасюк та О. Красівський, вибори - це передбачена конституцією та законами форма прямого народовладдя та участі громадян у політичному житті демократичних країн. Це один із способів інституювання публічної влади, інакше кажучи механізм 
створення органів влади, що є водночас і найбільш ефективним знаряддям тимчасової політичної відповідальності осіб, які виконують публічно-управлінські функції. У процесі виборів здійснюється безпосереднє обрання певних осіб (партій) для виконання відповідних функцій управління шляхом голосування та подальше формування представницьких органів управління. На практиці, у загальному вигляді, вибори $є$ формою колективного рішення суспільної групи щодо тієї чи іншої особи (політичної сили). При цьому головним у виборах $\epsilon$ обрання особи чи партії, наділення іiї владою та делегування їй відповідних повноважень. У цьому контексті нам імпонує твердження, що вибори є цивілізованою, правовою формою отримання й оновлення влади, демократичний спосіб формування органів публічної влади [28, c. 53]. Адже дійсно сьогодні процес здобуття влади, який чітко регламентований на законодавчому рівні, відбувається не насильницьким шляхом (наприклад, проведення репресій, бунтів, здійснення державних переворотів тощо), як було раніше, а за допомогою обов'язкового врахування думки більшості, котра теоретично не має бути заангажована. До цього варто додати, що повноцінність і реальність виборів проявляється в умовах чесної конкурентної боротьби, в якій повинні брати участь два і більше кандидатів або політичних партій.

У конституціях багатьох країн світу зафіксовано, що єдиним сувереном влади є народ, який реалізує свої владні повноваження шляхом обирання тих, хто керуватиме державою. При цьому обранці не $\epsilon$ безпосередніми власниками влади, а лише їі носіями - виконують роль тимчасових менеджерів (управлінців), які розпоряджається невід'ємною владою народу. Таким чином, виборці самотужки за допомогою проведення загального голосування, за підсумками більшості голосів наймають тих осіб (політичних сил), кому вони доручають керувати країною, реалізовувати відповідні програми та саме головне - стояти на захисті прав й інтересів суспільства та задоволені його потреб [9, с. 5-6].

Якщо говорити про зміст поняття «місцеві вибори», то воно схоже із загальним поняттям «вибори», різниця (а більш правильно уточнення) полягає у тому, що під час голосування виражають свою волю лише ті громадяни, які проживають на території відповідних 
територіальних громад з метою формування складу місцевих представницьких органів та заміщення посад керівників громад. Місцеві вибори в залежності від походження назв місцевих представницьких органів (муніципалітет, комуна, провінція, регіон) називають по-різному [28, с. 56]. В Україні, відповідно до чинного законодавства, вибори до самоврядних представницьких органів називаються місцевими, що за своєю правовою природою є вільними та відбуваються на основі гарантованого Конституцією й іншими законами України виборчого права шляхом таємного голосування [29].

Проведення місцевих виборів в нашій державі грунтується на відповідних принципах, які є основними засадами для організації та проведення виборів із дотриманням найважливіших прав і свобод громадянина. Такими принципами є:

1) загальне виборче право, яке означає, що голосувати на місцевих виборах можуть лише громадяни України, які мають право голосу відповідно до ст. 70 Конституції України, належать до відповідних територіальних громад на території яких і відбувається голосування та проживають в межах відповідного територіального виборчого округу. Якщо ми говоримо про додаткові вибори депутатів сільської, селищної ради у контексті об'єднання громад, то голосувати на таких виборах можуть громадяни України, які мають право голосу відповідно до ст. 70 Конституції України та належать до громади, що приєдналася до об'єднаної територіальної громади в порядку, визначеному Законом України «Про добровільне об'єднання територіальних громад» і проживають у межах відповідного виборчого округу. При цьому належність громадянина до тої чи іншої територіальної громади та проживання його на відповідній території визначається його офіційно зареєстрованим місцем проживання [29]. Виходячи із зазначеного можна зробити висновок, що право голосувати на місцевих виборах мають лише ті особи, які належать до відповідної територіальної громади та проживають у межах відповідного територіального округу, що прямо підтверджується реєстрацією місця проживання у паспортах таких осіб. Інакше кажучи, якщо відсутня реєстрація місця проживання в паспорті особи, то така особа позбавляється права голосувати. А враховуючи те, що на сході нашої країни вже не один рік 
триває військовий конфлікт із Російською федерацією та Автономна Республіка Крим є тимчасово окупованою територією, багато людей вимушено стали переселенцями або з певних причин і досі продовжують мешкати на зазначених територіях. Як наслідок, такі особи, відповідно до положень діючого Закону України «Про місцеві вибори», позбавляються права голосувати. Однак з метою недопущення порушення конституційних прав громадян України Центральна виборча комісія прийняла на початку вересня минулого року Постанову «Про внесення змін до постанови Центральної виборчої комісії від 13 вересня 2012 р. № 893», відповідно до положень якої проголосувати зможуть не тільки близько півтора мільйона переселенців, а й мешканці окупованого сходу України та Автономної Республіки Криму. Для цього необхідно подати заяву про тимчасову зміну місця голосування у межах відведених законом строків [18]. Але не зважаючи на такі прогресивні нормативні зрушення у цьому контексті, переселенці зі сходу країни та Криму безпосередньо позбавлені права голосу на виборах міського голови чи депутатів міської ради. А на парламентських виборах вони зможуть проголосувати лише за депутатів, які обираються за партійними списками. Це означає, що переселенці можуть вплинути на обрання лише 225 із 450 депутатів Верховної Ради України, кількість яких є недостатньою для ухвалення закону (не менше як 226 депутатів парламенту) [22].

На нашу думку, такі законодавчі зміни є поверхневими й у повному обсязі не забезпечують реалізацію одного із важливих прав людини - право обирати та спотворюють саму ідею публічного управління. Більшість європейських країн, враховуючи динаміку розвитку суспільних відносин та швидкі темпи глобалізаційних процесів, пішли на деякі законодавчі поступки щодо можливості брати участь у місцевих виборах. Яскравим у цьому контексті $є$ приклад королівства Швеції. Так, відповідно до Закону Швеції «Про вибори» від 24 листопада 2005 р., право голосу на виборах мають особи, котрі офіційно зареєстровані у відповідних муніципалітетах, досягли 18 років і є громадянами Швеції чи Свропейського Союзу, Норвегії, Ісландії або ж іноземцями, які зареєстровані і проживають на території Швеції протягом останніх трьох років до дня виборів 
[7 с. 50]. 3 наведеного можна узагальнити, що в питанні участі в місцевих виборах основною вимогою є постійне фактичне проживання осіб на території Швеції останні три роки до дня виборів та офіційна їх реєстрація у відповідній комуні чи регіоні. Шведські законотворці вважають, що такі особи переймаються проблемами села, селища, міста, на території яких проживають та прагнуть до покращення соціально-економічного розвитку свого населеного пункту і, відповідно, свідомо підходять до питання обрання гідного кандидата чи партії для свого округу. Вважаємо, що демократична і соціально-правова спрямованість нашої держави та бажання вступити до Європейського Союзу є вагомим чинником для перегляду діючого виборчого законодавства, зокрема, розширення переліку осіб, які мають право брати участь у місцевих виборах. Адже надання правова голосу на виборах виключно громадянам України позбавляє права на волевиявлення тих осіб, які хоч і не є громадянами нашої держави, але безпосередньо із нею пов'язані, що, зазвичай, виражається у фактичному та офіційному їх проживанні на території України та веденні певної діяльності, що не заборонена законом. Можливо більшість людей виступлять проти долучення іноземців (чи осіб без громадянства) до публічного управління через участь у місцевих виборах, мотивуючи це тим, що управління місцевими справами мають здійснювати виключно громадяни України, які офіційно проживають на території тієї чи іншої громади. Однак розвиток економічних та інноваційно-технологічних відносин не стоїть на місці і прив'язка особи до місця іiі реєстрації, на сьогоднішній день, вже втрачає свою значимість. Держава прагнучи зробити публічні послуги більш доступними для населення в межах чинного законодавства дозволяє їх отримувати у тому місці й у той спосіб, що $є$ більш зручнішим для самих людей. Тому враховуючи зазначене, вбачаємо за доцільне внести зміни до Закону України «Про місцеві вибори» розширивши перелік вимог, що висуваються до виборців, і закріпити право участі в голосуванні громадян України, які на день виборів фактично проживають на території будь-якого населеного пункту України протягом останніх трьох років (вважаємо, що це достатній період часу для вивчення й перейняття проблем 
тієї місцевості, де така особа мешкає, а також для розуміння потреб і подальших напрямів розвитку відповідної громади).

Додатково хотілося б звернути увагу, що відповідно до чинного законодавства не мають право голосувати на місцевих виборах військовослужбовці строкової служби, громадяни України, які проживають за кордоном, а також особи, визнані судом недієздатними, та громадяни України, які за вироком суду перебувають у місцях позбавлення волі. Ці особи вважаються такими, що у відповідний період не належать до жодної територіальної громади та не мають права голосу на місцевих виборах. На наш погляд, такі нормативні приписи, з одного боку, звужують право громадянина вільно обирати, закріплене в ч. 1 ст. 38 Конституції України [11], а з іншого - $\epsilon$ лише тимчасовими обмеженнями, пов'язаними із тим, що такі особи у повному обсязі не володіють ситуацією (інформацією) щодо відповідної території, де відбуваються місцеві вибори, їх явку на вибори практично неможливо забезпечити не порушуючи межі того режиму, в якому вони перебувають або просто такі особи не усвідомлюють своїх дій (наприклад, психічно хворі). Враховуючи такі умови, говорити про реальність та ефективність голосування таких осіб неможливо. Можна вважати, що на сьогодні принцип загальності виборчого права стосовно місцевих виборів відповідного до чинного законодавства повною мірою не реалізується, що має свої практичні негативні наслідки у питанні представлення інтересів членів громади у процесі здійснення публічного управління на місцях;

2) рівне виборче право - представляє собою участь громадян України у відповідних місцевих виборах, кожен з яких має лише один голос, що може бути використаний тільки на одній виборчій дільниці, на якій включена та чи інша особа до списку виборців, на рівних засадах - заборона привілеїв чи обмежень за ознаками раси, кольору шкіри, політичних, релігійних та інших переконань, статі, етнічного та соціального походження, майнового стану, за мовними або іншими ознаками [29]. Відповідно до положень нового Закону України «Про місцеві вибори» цей принцип розповсюджується і на кандидатів у депутати місцевих рад, один із аспектів якого полягає у забезпеченні гендерної квоти. Це одна з найреволюційніших новел 
цього Закону, що свідчить про формування сучасного вітчизняного законодавства європейського спрямування та зміну методів і механізмів публічного управління через новосформованих представницьких самоврядних органів влади. Так, відповідно до ч. 3 ст. 4 названого Закону, представництво осіб однієї статі у виборчих списках кандидатів у депутати місцевих рад у багатомандатних виборчих округах має становити не менше 30 \% від загальної кількості [29]. На жаль, в Законі не передбачено відповідальності за недотримання зазначеної правової норми. Тому з метою врегулювання колізії в одному правому акті Центральна виборча комісія в Постанові «Про Роз'яснення щодо застосування деяких положень Закону України «Про місцеві вибори» під час реєстрації кандидатів у депутати Верховної Ради Автономної Республіки Крим, кандидатів у депутати обласних, районних, міських, районних у містах, сільських, селищних рад, кандидатів на посаду сільського, селищного, міського голови та старости села, селища, висунутих місцевими організаціями політичних партій на чергових, позачергових та перших місцевих виборах» від 23 вересня 2015 року № 362 роз'яснила, що відмова реєструвати кандидатів через недотримання гендерної квоти не допускається, оскільки дане положення відсутнє в переліку підстав для відмови у реєстрації, закріпленому в ч. 1 ст. 46 Закону України «Про місцеві вибори». Більше того, враховуючи те, що Україна ратифікувавши Міжнародний пакт про громадянські та політичні права та Конвенцію ООН про ліквідацію всіх форм дискримінації щодо жінок Україна зобов'язалася «забезпечити рівне для чоловіків і жінок право користування всіма громадянськими і політичними правами» (ст. 4 Пакту) [16] та «вживати усіх відповідних заходів щодо ліквідації дискримінації по відношенню до жінок у політичному і суспільному житті» (ст. 7 Конвенціi) [12]. Тому процес розробки і прийняття вітчизняних нормативно-правових актів та здійснення публічного управління, на наш погляд, має відбуватися з обов'язковим урахуванням гендерної рівності в усіх суспільних сферах. До речі, наша країна вже йде таким шляхом, хоча і доволі повільно. Наприклад, у 2005 р. Верховною Радою України було прийнято Закон «Про забезпечення рівних прав та можливостей жінок і чоловіків», метою якого є досягнення пари- 
тетного становища жінок і чоловіків у всіх сферах життєдіяльності суспільства шляхом правового забезпечення рівних прав та можливостей жінок і чоловіків, ліквідації дискримінації за ознакою статі та застосування спеціальних тимчасових заходів, спрямованих на усунення дисбалансу між можливостями жінок і чоловіків реалізовувати рівні права, надані їм Конституцією і законами України [31]. На основі цього Закону були спроби сформувати Кабінет Міністрів України із дотриманням гендерної рівності, проте кінцевого успіху досягти так і не вдалося (як бачимо на сьогоднішній день в Уряді країни переважає більша частка чоловіків ніж жінок). Не винятком став і новий Закон України «Про місцеві вибори», однак як зазначалося вище, окремі його положення у контексті гендерної рівності до кінця не відпрацьовані, що допускає можливість невілювати проголошений країною принцип рівних можливостей жінок і чоловіків. Враховуючи зазначене та 3 метою повноцінного виконання взятих Україною на себе відповідних міжнародно-правових зобов'язань, вважаємо за необхідне внести зміни до ч. 1 ст. 46 Закону України «Про місцеві вибори», доповнивши перелік підстав для відмови в реєстрації кандидата в депутати недотриманням гендерної квоти. Лише тоді ми зможемо говорити про дійсно рівне виборче право кожного громадянина України;

3) пряме виборче право, яке відповідно до ст. 4 Конвенції про стандарти демократичних виборів, виборчих прав і свобод у державах-учасницях Співдружності Незалежних Держав означає, що громадяни голосують на виборах відповідно за кандидата та (або) список кандидатів чи проти кандидата, кандидатів та (або) списку кандидатів безпосередньо, чи проти всіх кандидатів та (або) списків кандидатів [13]. Безпосередньо у ст. 5 Закону України «Про місцеві вибори» зазначено, що громадяни реалізують своє виборче право шляхом голосування за кандидатів, висунутих та зареєстрованих у порядку, передбаченому цим Законом [29]. Цікавим аспектом у цьому є відсутність у виборчих бюлетенях графи «не підтримую жодного кандидата» (проти всіх), яка зникла в 2011 р. внаслідок схвалення Верховною Радою України відповідних поправок до виборчого законодавства у зв'язку із іï «непотрібністю». До речі, виборче зако- 
нодавство майже всіх європейських країн у виборчих бюлетенях не передбачає наявність пункту «проти всіх». Винятком є такі країни, як Греція, Іспанія і Франція. Відсутність такої графи, на наш погляд, позбавляє громадян України громадянської свободи і відповідальності за свій вибір, підриваючи демократичні засади країни. Також це створює перешкоди для виявлення реального ставлення громадян України до діючої влади та майбутніх кандидатів, що створює додаткові можливості для маніпулювання суспільною свідомістю і вибором українського народу. 3 метою запобігання таких ситуацій на розгляд Верховної Ради України 21 січня 2019 р. було висунуто проект Закону «Про внесення змін до деяких законів України щодо волевиявлення виборців» № 9492, відповідно до положень якого у громадян України знову з'явиться альтернатива - прийти на дільниці, але не підтримати жодного кандидата чи партію. Інакше кажучи не голосувати вимушено за будь-кого, коли є бажання не підтримати жодного кандидата чи партію. У цьому законопроекті вказано якщо після встановлення результатів в одномандатному окрузі з'ясується, що кількість позначок у графі «Проти всіх» перевищила половину голосів тих, хто взяв участь у волевиявленні, вибори вважатимуться такими, що не відбулися. А кандидати, які отримали вотум недовіри громадян, у повторних виборах не зможуть брати участь [20]. Ми вважаємо, що відновлення графи «проти всіх» у виборчих бюлетенях позитивно відобразиться на утвердженні України як сучасної демократичної країни, усі думки громадян якої враховуються, а принцип народного волевиявлення у повній мірі реалізується;

4) вільність виборів, що означає добровільність участі (або не участі) громадян у місцевих виборах та вільне висловлення своєї волі при голосуванні. При цьому застосування будь-яких форм насильства, погроз, обману, підкупу чи інших дій, що перешкоджають вільному волевиявленню виборця під час голосування забороняється [29]. Тобто мова йде про заборону будь-якого психологічного чи фізичного впливу на виборця, як протягом всієї виборчої кампанії, так і безпосередньо у момент його голосування на територіальній виборчій дільниці. Незалежно від місця роботи чи навчання, а також фінансово-матеріального чи сімейного стану виборця, чинити 
на нього тиск у будь-який спосіб, спекулюючи цими чинниками не можна. Проте на практиці ми зустрічаємо не поодинокі випадки тиску на виборців, які, наприклад, перебувають на державній службі або навчаються у державних закладах освіти з боку діючої влади, що має значний фінансово-адміністративний ресурс для здійснення таких дій. Звичайно це порушує загальноприйняті на світовому рівні стандарти проведення виборів, проте в Україні за такі дії не було реально притягнуто до відповідальності жодної особи. У більшій мірі це пов'язано із тим, що самі виборці не висловлюють категоричності проти зазначених дій та не повідомляють у відповідні правоохоронні органи про такі випадки, оскільки самі заінтересовані (часто фінансово) у спотворенні власного вибору;

5) таємність голосування, як один із загальновизнаних принципів виборчого права, закріплений у ст. 25 Міжнародного пакту про громадянські і політичні права [16], в ст. 3 Протоколу до Конвенції про захист прав людини і основоположних свобод [21], у ст. 71 Основного Закону України, який дублюється у ст. 141 цього ж Закону стосовно місцевих виборів [11] та в ст. 7 Закону України «Про місцеві вибори». За своєю ідеєю таємне голосування протиставляється голосуванню відкритому чи поіменному. Принцип таємного голосування полягає у забороні розголошення чи повідомлення іншим особам змісту волевиявлення кожного конкретного виборця. На думку Ю. Ключковського, недопущення контролю за волевиявленням виборців або зовнішнього впливу на волевиявлення виборця чи тиску з метою отримання інформації про зміст поданого голосу $\epsilon$ вже наслідками, що випливають із такої заборони. [10, с. 33]. У більш широкому сенсі принцип таємності голосування, як вважає С. Яворський, слід розглядати у трьох аспектах:

- як наказ про заборону ознайомитися із змістом вже відданих голосів до закінчення голосування. Така вимога має організаційно-процедурний характер і робить акцент саме на часових межах час закінчення голосування;

- як наказ про забезпечення секретності рішення кожного окремого виборця, що розкриває традиційне розуміння принципу таємності голосування; 
- як гарантія виборцям, що їх волевиявлення не спричинять негативні або позитивні (заохочення за «правильний вибір») для них наслідки. Ця вимога гарантує захист усіх виборців у разі порушення таємності прийнятого ним рішення або відмови виборця від порушення такої таємниці на вимогу третіх осіб [6, с. 474].

Відповідно до вітчизняного законодавства, цей принцип означає заборону контролю за волевиявленням виборців, за допомогою фотографування, відеофіксації чи в будь-який інший спосіб у кабінах для таємного голосування, а також заборона демонстрації виборцем результатів власного волевиявлення як у приміщенні для голосування, так і поза ним. Окрім того, забороняється членам виборчих комісій або іншим особам вчиняти будь-які дії чи розголошувати відомості, що дають можливість встановити зміст волевиявлення конкретного виборця [29]. Виходячи із зазначеного ми можемо з упевненістю сказати, що принцип таємності голосування під час проведення місцевих виборів в Україні забезпечується, як у процесі безпосереднього голосування виборців, так і після нього;

6) особисте голосування, що тісно пов'язане із принципом таємності голосування, як один із важливих принципів виборчого права $є$ гарантією прозорих і демократичних виборів та зменшує можливість маніпулювання виборчими голосами. На наш погляд, синонімом слова «особистий» можна назвати слово «самостійний» (здатність діяти самому без сторонньої допомоги чи впливу). У процесі голосування виборець самостійно приймає рішення стосовно власного голосу і не має право голосувати за інших осіб або передавати своє право голосу будь-якій іншій особі. Однак відповідно до ч. 2 ст. 8 Закону України «Про місцеві вибори», винятком у цій ситуації буде допомога іншому виборцю, який має особливі потреби i внаслідок цього не може самостійно заповнити виборчий бюлетень чи опустити його у виборчу скриньку, при умові виконання всіх дій і відповідно до волевиявлення такої особи та в порядку, встановленому ч. 9 ст. 77 зазначеного Закону. Такі дії не будуть вважатися голосуванням замість іншої особи [29]. Проте у разі вчинення інших дій, які спричиняють порушення принципу особистого голосування карається законом у вигляді притягнення винних осіб до криміналь- 
ної відповідальності. Інакше кажучи особа має особисто отримати виборчий бюлетень та власноруч поставити підпис у відповідному місці, самостійно заповнити бюлетень і без сторонньої допомоги опустити його у спеціальну прозору виборчу скриньку, яка належним чином опломбована.

Стосовно вищезазначених основоположних принципів виборчого процесу, окремо хотілося б підкреслити, що їх законодавче закріплення і суворе дотримання є невід’ємною частиною суспільно-політичного життя України та однією з ознак дієвості демократії на теренах нашої країни. Більше того, повна реалізація принципів виборчого процесу для українського народу є гарантією легітимації того, кого обрала більшість та суспільного спокою і впевненості у дієвості власних дій (голосів).

Протягом усього період незалежності нашої країни виборчі системи змінювалися неодноразово, що прямо було пов'язано зі зміною тієї чи іншої політичної сили. На сьогоднішній день відповідно до нового Закону України «Про місцеві вибори», вибори до органів місцевого самоврядування проводяться одночасно за трьома виборчими системами:

1) мажоритарна система відносної більшості в одномандатних виборчих округах (вибори депутатів сільських/селищних рад, старост, сільських/селищних та міських голів (у містах із менш ніж 90 тис. виборців)), на які поділяється територія відповідно села, селища, міста та новоутвореної об'єднаної сільської, селищної чи міської громади відповідно до Закону України «Про добровільне об'єднання територіальних громад». За такої умови, керуючись правилами цієї виборчої системи, якщо до виборчого бюлетеня на день виборів включено не менше двох кандидатів в депутати (на посаду сільського, селищного, міського голови та старости), обраним вважається той кандидат, за якого подано більше голосів виборців ніж за інших кандидатів. У випадку, коли два і більше кандидатів у депутати (на посаду сільського, селищного, міського голови та старости) за результатами виборів набрали найбільшу й однакову кількість голосів 3-поміж інших кандидатів, територіальна виборча комісія призначає повторне голосування за ці кандидатури (так би мовити другий тур). У разі, якщо голосу- 
вання проводилося лише за єдиного кандидата в депутати (на посаду сільського, селищного, міського голови та старости), представленого у виборчому бюлетені, то така особа вважається обраною при умові, що за ії кандидатуру проголосувало більше половини виборців, які взяли участь у голосуванні. Якщо ж єдиний кандидат у депутати (на посаду сільського, селищного, міського голови та старости) набрав менше половини голосів виборців, котрі брали участь у голосуванні, тоді територіальна виборча комісія приймає рішення про визнання відповідних місцевих виборів такими, що не відбулися [29];

2) мажоритарна система абсолютної більшості (вибори міських голів у містах із більш ніж 90 тис. виборцями) в єдиному одномандатному виборчому окрузі, що збігається із територією міста згідно з існуючим адміністративно-територіальним устроєм або територією об'єднаної міської територіальної громади. Такий вид виборчої системи означає, що будь-який із кандидатів на посаду міського голови за результатами виборів повинен набрати абсолютну більшість голосів виборців. Якщо ж жоден із кандидатів не отримав абсолютної підтримки від виборців, рішенням відповідної територіальної виборчої комісії призначаються повторні вибори. Водночас участь у другому турі беруть лише ті кандидати, які набрали найбільшу кількість голосів виборців за підсумками попереднього голосування. Перемогу на виборах за результатами повторного голосування отримує той кандидат, який набрав більшу кількість голосів виборців. У випадку коли, у виборчих перегонах змагаються два кандидати на посаду міського голови, і жоден із них не отримав більше половини голосів виборців, котрі брали участь у голосуванні, територіальна виборча комісія приймає рішення про визнання відповідних виборів такими, що не відбулися. Якщо у виборчому бюлетені зазначено лише одного кандидата, то для отриманням ним перемоги необхідно набрати більше половини голосів виборців. У випадку не набрання такою особою необхідної кількості голосів, рішенням відповідної територіальної виборчої комісії вибори оголошуються такими, що не відбулися [29];

3) пропорційна система в багатомандатному виборчому окрузі за виборчими списками місцевих організацій політичних партій із 
закріпленням кандидатів за територіальними виборчими округами, на які поділяється багатомандатний виборчий округ, що збігається із територією відповідно Автономної Республіки Крим, області, району, району в місті, територією міста згідно з існуючим адміністративно-територіальним устроєм або територією утвореної відповідно до Закону України «Про добровільне об’єднання територіальних громад» об'єднаної міської територіальної громади (вибори депутатів обласних, районних, міських, районних у містах рад) [29]. Керуючись умовами пропорційної системи депутатські мандати у відповідних виборчих округах отримають лише ті кандидати в депутати, які за результатами виборів набрали не менше 5 \% голосів виборців по відношенню до загальної кількості голосів виборців, відданих за місцеві політичні партії. До речі, окремо хотілося $6 з$ акцентувати увагу на формуванні виборчих списків політичних партій: першим у списках вказується, так би мовити, основний кандидат (частіш за все, це саме впізнане обличчя для населення), а далі йдуть інші кандидати в алфавітному порядку (за прізвищем) із зазначенням територіальних виборчих округів, за якими вони закріплюються. Проте кількість кандидатів у депутати, включених до виборчих списків місцевих партій, не може перевищувати кількості депутатів відповідної ради плюс одна особа.

I якщо перші дві системи є простими у використанні й у кінцевому підрахунку голосів за кандидатів та зрозумілими для громадськості, яка обирає свої представників. Окрім того, на наш погляд, використання таких систем $є$ реальним проявом такої ознаки демократії, як вибір більшості. Стосовно третьої системи, то ії модифікований варіант спричинив низку зауважень із боку громадськості та експертів. Це було викликано запровадженням 5\% прохідного бар'єру і забороною самовисування у депутати відповідних рад. А також тим, що такий варіант виборчої системами допускає можливість отримання депутатських мандатів відразу декількома депутатами від одного виборчого округу, при цьому інші округи виявляються не представленими жодним депутатом. Так, наприклад, за результатами виборів до Київської міської ради, які відбулися 25 жовтня 2015 р., 85 округів мають по одному народному обранцю, 15 - по два 
депутати, а 20 округів взагалі не мають власного представника у цій раді [17]. При цьому Київська міська рада є не єдиним прикладом, такі ситуації склалися і в окремих радах Волинської, Запорізької, Одеської, Харківської областей тощо. Безпосередньо в Миколаївській міській раді із 54 існуючих виборчих округів 34 округи мають по 1 депутату, 8 - по 2, а 12 - не мають жодного представника в раді. У відсотковому співвідношенні представництво окремих частин м. Миколаєва та їх мешканців в міській раді виглядає наступним чином: $63 \%$ території міста представлено по одному депутату, $15 \%$ - по 2 депутати та $22 \%$ - не представлено жодним із депутатів. Це говорить про те, що майже четверта частина міста залишається поза увагою, як у фінансово-матеріальному, так і не в матеріальному сенсах. Відповідно допускаємо, що інтереси мешканців міста, які мають по два представника у раді, будуть задоволені у більш короткі строки та у значно якіснішому вигляді. В аналогічному становищі перебувають і мешканці м. Луцьк. Так, за результатами виборів із 42 виборчих округів 23 округи (55\% території міста) мають по 1 депутату, 7 (17 \% території міста) - по 2, а 12 (28 \% території міста) - не мають жодного представника у раді (див. рис. 1) [27].

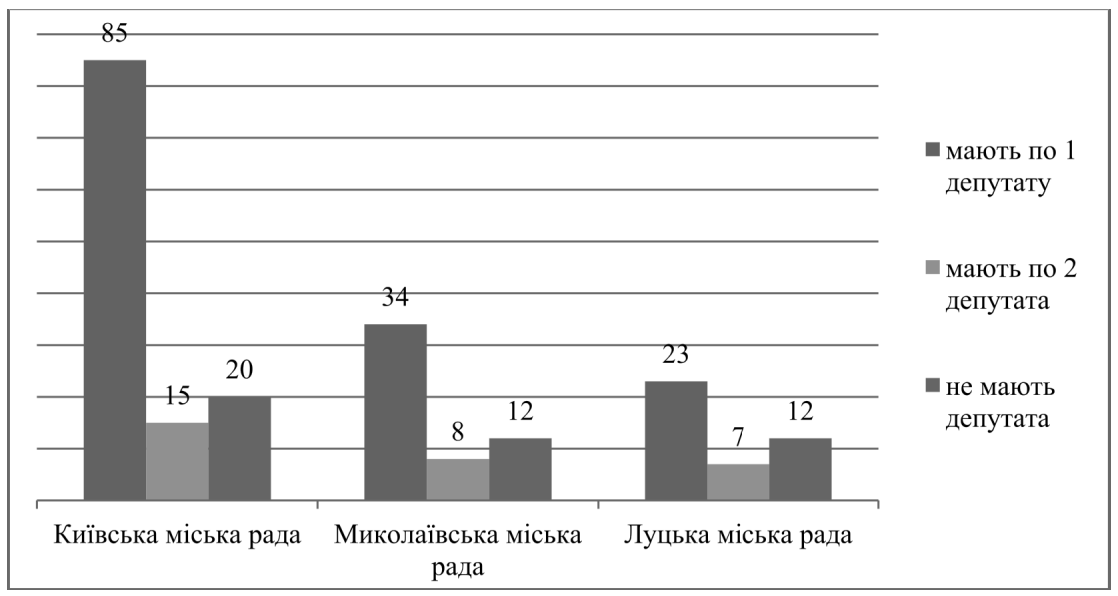

Puc. 1. Співвідношення кількості виборчих округів та обраних від них депутатів в розрізі Київської, Миколаӥвської та Луиької місиевих рад 
Вважаємо, що такі законодавчі норми руйнують основний принцип представницької демократії шляхом позбавлення виборців округу можливості мати свого представника у відповідній раді. Загальновідомо, що будь-які місцеві ради, як колегіальні органи, представляють інтереси територіальних громад, мешканці яких обирали до них депутатів. Згідно зі ст. 10 Закону України «Про статус депутатів місцевих рад» від 11 липня 2002 р. № 93-IV, безпосередньо до обов'язків депутата місцевої ради у виборчому окрузі входить звітування про виконану роботу, прийом виборців, проведення громадських слухань. Окрім цього, відповідно до ст. 17 цього ж Закону виборці мають право давати своєму депутатові місцевої ради певні доручення [30]. У випадку, коли жоден кандидат від того чи іншого виборчого округу не отримав мандат, як наслідок виникає низка запитань: хто саме буде представляти населення такого округу? хто буде виконувати обов'язки передбачені Законом України «Про статус депутатів місцевих рад» перед виборцями? кому із обраних депутатів виборці будуть давати свої доручення у разі такої необхідності? За таких умов люди просто кинуті напризволяще, маючи два варіанти вирішення ситуація, яка склалася - або розв'язувати, проблеми, що виникають самотужки, або чекати нових виборів і сподіватися на успішне обрання власного депутата до місцевої ради. Адже усі ми чудово розуміємо, що будь-який депутат місцевої ради, перш за все, буде дбати про свій округ та його мешканців, думаючи про власний рейтинг та перемогу у наступних виборах, ніж піклуватися про населення інших округів, які не мають свого депутата. Так само, як було вже вище зазначено, у більш вигідному становищі перебувають мешканці тих виборчих округів, які мають по декілька своїх представників у раді, тим самим, наприклад, отримуючи значніші об'єми коштів на вирішення місцевих проблем та задоволення власних потреб.

Більш детально хотілося б розглянути питання подолання відсоткового бар'єру для проходження до місцевої ради. Діючий на сьогоднішній день Закон України «Про місцеві вибори» закріпив введення 5 \% прохідного бар'єру на виборах депутатів Автономної Республіки Крим, обласних, районних, міських і районних у містах 
рад. У порівнянні такий бар'єр на місцевих виборах у 2010 р. становив лише $3 \%$. Застосування 5 \% прохідного бар'єру на місцевих виборах, аналогічно із виборами до Верховної Ради України у 2012 p., 2014 р. та 2019 р., породило специфічну конкурентну боротьбу як між різними політичними партіями, так і в середині кожної із них. Як наслідок, невеликі регіональні партії та нещодавно створені політичні сили не мають можливості отримати депутатські мандати в новообраних місцевих радах. Проте з іншого боку такий високий прохідний бар'єр, на наш погляд, є позитивним моментом у подальшому розподілі політичних сил в місцевих радах, нормальному їх функціонуванні та продуктивності роботи (не буде розпорошеності у поглядах стосовно напрямів і способів розвитку територіальних громад, обрання пріоритетів в соціальних і економічних сферах тощо). Однак разом із тим, кожен з кандидатів зацікавлений у тому, щоб його однопартійці здобули якомога менше відсотків голосів у своїх виборчих округах. Оскільки у разі подолання партією 5 \% бар'єру, визначення переліку обраних депутатів до ради відбувається саме шляхом співставлення відсотків підтримки виборцями кандидатів у відповідних округах. До речі, в проекті Закону України «Про місцеві вибори» від 14 липня 2015 р. № 595-VIII було прописано, що формування депутатського корпусу в місцевих радах відбувається на основі співставлення кількості набраних голосів, а не відсоткового співвідношення [19]. На жаль, ці положення не були включені до кінцевої редакції цього Закону. Такі законодавчі нормативи спричинили виникнення парадоксальних ситуацій, коли одні кандидати завдяки підтримки виборців принесли своїм партіям більше голосів, ніж інші їх однопартійці, однак не отримали депутатські мандати через суттєві розбіжності у розмірах виборчих округах здобувши менший відсоток голосів у своєму окрузі. Вважаємо, що такі ситуації виникатимуть і надалі у процесі підведення підсумків результатів місцевих виборів до тих пір, поки не будуть внесені відповідні зміни до виборчого законодавства України. Насамперед необхідно перевірити окремі положення Закону України «Про місцеві вибори» на відповідність Конституції України і тільки тоді, керуючись отриманими результатами, приймати рішення про 
повну відмову від пропорційної виборчої системи чи ії модифікацію (наприклад, зобов'язати вже сформованих місцевих рад призначати відповідальних депутатів за ті виборчі округи, які залишилися без власного представника), враховуючі власні потреби та іноземний досвід.

Іще одним важливим моментом стосовно виборів до органів місцевого самоврядування, який спричинює ряд дискусій, як було вже вище зазначено, є законодавчо визначений механізм самовисування кандидатів. Відповідно до Закону України «Про місцеві вибори», право самовисування надається тільки кандидатам на посади сільського, селищного та міського голів, а також кандидатам в депутати сільських та селищних рад. Якщо ж говорити про міські ради, то відповідно до ст. 10 названого Закону, право висування кандидатів реалізується безпосередньо громадянами України виключно через республіканські в Автономній Республіці Крим, обласні, районні, міські, районні у містах організації політичних партій [29]. Такі законодавчі обмеження, як вважають більшість науковців та політичних експертів, думки яких ми поділяємо, штовхають потенційних кандидатів на кардинальні дії - у різний спосіб домовлятися із провідними особами тих чи інших політичних партій, 3 метою одержання місця у списку партії. Цілком допускаємо, що у результаті таких домовленостей відповідні особи будуть вимушені йти на певні компроміси у питаннях власного бачення розвитку окремої територіальної громади чи усього регіону, брати на себе різного роду зобов'язання чи навіть сплачувати партіям або окремим іiі членам кошти [17].

У підсумку зазначимо, що місцеві вибори є надважливим проявом демократії в нашій країні, коли публічне управління здійснюють не лише народні обранці або державні службовці різної категорії, а безпосередньо кожен громадянин, приходячи на вибори та роблячи свій власний свідомий вибір, спрямований на покращення існуючого фінансово-матеріального та соціально-інфраструктурного стану тієї чи іншої територіальної громади або окремої ії частини. Тому саме ставлення до місцевих виборів, як з боку законотворців та кандидатів в депутати (на посаду сільського, селищного, міського 
голови та старости), так і з боку виборців має бути зовсім іншим, ніж тим, яким воно є на сьогоднішній день. Мається на увазі, що виборче законодавство не повинно змінюватися напередодні або у розпал самого виборчого процесу, як це вже стало нормою та звичним ділом в нашій державі, а самі виборці мають відповідально ставитись до своїх обов'язків як громадян України та неодмінно йти на вибори, висловлюючи свою громадську позицію. Вважаємо, що це у комплексі сприяло б стабілізації нормативно-правового регулювання виборчого процесу, знизило морально-психологічний вплив на електорат та забезпечило високий рівень правової культури усіх учасників виборчого процесу.

Висновок. Таким чином, враховуючи вищевикладене можна узагальнити, що місцеві вибори $є$ однією із форм прямого народовладдя (безпосереднє вільне волевиявлення мешканців територіальних громад), передбачена Конституцією та Законами України, яка полягає у формуванні складу органів місцевого самоврядування шляхом таємного голосування, керуючись загальним, рівним та прямим виборчим правом. Вибори до органів місцевого самоврядування в Україні проводяться одночасно за трьома виборчими системами, остання (пропорційна система) з яких як в теорії, так і на практиці викликає низку запитань та спричинює ряд проблем. Для їх розв'язання необхідно грунтовно і раціонально підходити до внесення змін в Закон України «Про місцеві вибори» та інші супутні нормативно-правові акти, враховуючи національні особливості й іноземний досвід, а також часові межі щодо можливості змінювати виборче законодавство. До цього ще можна додати загально-масштабну популяризацію необхідності й важливості місцевих виборів та участі населення в них, доведення до відома громадян конституційно-правових засад організації та проведення місцевих виборів у доступний і зрозумілий для них спосіб.

\section{Стаття надійшла до редакції: 27.06.2019}




\section{SOME ASPECTS OF HOLDING LOCAL ELECTIONS IN UKRAINE: PROBLEMS AND WAYS OF SOLVING THEM}

Anastasia Shulga, PhD in Public Administration, Senior Lecturer, Institute of Public Administration, Petro Mohyla Black Sea National University, Mykolaiv, Ukraine

The article is analyzes some legal and practical aspects of holding local elections in Ukraine, identifies existing problems in the electoral process and suggests ways to solve them. At the beginning of the study, is outlines the concept of «elections» and «local elections». Different views of scientists on the interpretation of these two concepts are given. The main part of the article is devoted to characterizing the principles on which local elections in our country are based. Such principles are: universal suffrage, equal suffrage, direct suffrage, freedom of election, secrecy of voting, personal voting. The study found that full implementation of each of these principles is currently impossible due to the imperfection of the current electoral legislation, the presence of military conflict in eastern Ukraine and annexation of the Autonomous Republic of Crimea, low level of legal consciousness and education of some citizens. Generalized, that the legislative consolidation of the fundamental principles of the electoral process and their strict adherence are: 1) an integral part of Ukraine's socio-political life; 2) one of the signs of the effectiveness of democracy in Ukraine; 3) a guarantee of the legitimacy of the one elected by the majority and of public tranquility and confidence in the effectiveness of their own actions (votes). The electoral systems existing in Ukraine are characterized. It is substantiated, that the first two electoral systems are easy to use and ultimately vote for candidates and understandable to the public, whom elect their representatives. It is revealed that the existing modified version of the third electoral system (proportional) destroys the basic principles of representative democracy, generates specific competition both between different political parties and in the middle of each of them. At the end of the article, it was concluded that local elections are a crucial manifestation of democracy in Ukraine, when public administration is carried out not only by members of parliament 
and local councils or civil servants of different categories, but directly by every citizen, coming to the polls and making their own conscious choices.

Keywords: elections, local elections, election principles, electoral systems, deputy.

\section{Received: 27.06.2019}

\section{References}

1. Akhtenberh, N. (1994). Hosudarstvennoe pravo Hermanyy [German state law]. Moskva: Ynstytut hosudarstva y prava Ran [in Russian].

2. Banaszak, B. (2004). Porównawcze prawo konstytucyjne współczesnych państw demokratycznych [Comparative constitutional law of modern democratic states]. Kraków: Zakamycze [in Polish].

3. Banaszak, B. (2012). Prawo konstytucyjne [Constitutional law]. Warszawa [in Polish].

4. Bilodida, I.K. (1970). Slovnyk ukrayins'koyi movy [Dictionary of the Ukrainian language]. (Vols. 11). Kyyiv: Naukova dumka [in Ukrainian].

5. Buczkowski, J. (1998). Podstawowe zasady prawa wyborczego III Rzeczypospolitej [Basic principles of the electoral law of the Third Polish Republic]. Lublin: Wydawnictwo UMCS [in Polish].

6. Czaplicki, K.W., Dauter, B., Jaworski, S.J., Kisielewicz, A., Rymarz, F. (2014). Kodeks wyborczy. Komentarz LEX [Electoral Code. Comment LEX]. Warszawa: LEX (Walter Kluwer) [in Polish].

7. Hrobova, V.P. (2015). Vyborcha systema mistsevykh orhaniv vlady u Shvetsiyi: dosvid dlya Ukrayiny [The local government electoral system in Sweden: experience for Ukraine]. Naukovyy visnyk Mizhnarodnoho humanitarnoho universytetu - Scientific Bulletin of the International Humanities University, 15, 48-50 [in Ukrainian].

8. Il'inskiy, I.P., Strashun, B.A., Yastrebov, V.I. (1985). Gosudarstvennoye pravo zarubezhnykh sotsialisticheskikh stran [State Law of Foreign Socialist Countries]. Moskva: «Mezhdunarodnyye otnosheniya» [in Russian].

9. Klymkova, I.I., Ostapenko, M.A. (2011). Vybory i vyborchi systemy [Elections and Electoral Systems]. Kyyiv: DP «Vydavnychyy dim «Personal» [in Ukrainian]. 
10. Klyuchkovs'kyy, Y.B. (2017). Pryntsyp tayemnoho holosuvannya [The principle of secret ballot / Yu. Klyuchkovsky]. Naukovi zapysky NaUKMA Scientific Notes of NaUKMA, 200, 32-40 [in Ukrainian].

11. Konstytutsiya Ukrayiny pryiniata 28 chervnya 1996 roku No. 254k/96VR [Constitution of Ukraine from June 28 1996, No. 254k/96-VR]. zakon.rada. gov.ua. Retrieved from https://zakon.rada.gov.ua/laws/show/254\%D0\%BA/96$\% \mathrm{D} 0 \% \mathrm{~B} 2 \% \mathrm{D} 1 \% 80$ [in Ukrainian].

12. Konventsiya Orhanizatsiyi $\mathrm{Ob}^{\prime \prime}$ yednanykh Natsiyi pro likvidatsiyu vsikh form dyskryminatsiyi shchodo zhinok pryiniata 18 hrudnya 1979 roku [United Nations Convention on the Elimination of All Forms of Discrimination against Women from December 18 1979]. zakon.rada.gov.ua. Retrieved from https://zakon.rada.gov.ua/laws/show/995_207 [in Ukrainian].

13. Konventsiyi pro standarty demokratychnykh vyboriv, vyborchykh prav i svobod u derzhavakh-uchasnytsyakh Spivdruzhnosti Nezalezhnykh Derzhav pryiniata 7 zhovtnya 2002 roku [Convention on the Standards of Democratic Elections, Electoral Rights and Freedoms in the States Parties to the Commonwealth of Independent States from October 7 2002]. zakon.rada.gov.ua. Retrieved from https://zakon.rada.gov.ua/laws/show/997_622 [in Ukrainian].

14. Korniyenko, M.I. (1993). Vyborche zakonodavstvo dlya orhaniv mistsevoho samovryaduvannya [Electoral Legislation for Local SelfGovernment Bodies]. Politolohichnyy slovnyk - Political Science Dictionary, 1, 17-20[in Ukrainian].

15. Lavrynovych, O.V. (2000). Konstytutsiyne zabezpechennya narodovladdya $\mathrm{v}$ Ukrayini [Constitutional provision of democracy in Ukraine]. Viche - Viche, 2(95), 3-11 [in Ukrainian].

16. Mizhnarodnyy pakt pro hromadyans'ki i politychni prava pryiniatyi 16 hrudnya 1966 roku [International Covenant on Civil and Political Rights from December 16 1966]. zakon.rada.gov.ua. Retrieved from https://zakon.rada.gov. ua/laws/show/995_043. 20 [in Ukrainian].

17. Pashyns'kyy, A.I. (2015). Novi vyklyky predstavnyts'kiy demokratiyi: 7 nedolikiv zakonu «Pro mistsevi vybory» ta shlyakhy yikh vyrishennya [New Challenges to Representative Democracy: 7 Disadvantages of the Law on Local Elections and Ways to Solve It]. Yurydychna hazeta - Law Gazette, 47(493). Retrieved from http://yur-gazeta.com/publications/practice/inshe/novi-viklikipredstavnickiy-demokratiyi-7-nedolikiv-zakonu-pro-miscevi-vibori-ta-shlyahiyih-virishe.html [in Ukrainian].

18. Postanova Tsentral'noyi vyborchoyi komisiyi Pro vnesennya zmin do postanovy Tsentral'noyi vyborchoyi komisiyi vid 13 veresnya 2012 roku No. 
893: pryiniata 5 veresnya 2018 roku No. 129 [Resolution of the Central Election Commission On amending the Resolution of the Central Election Commission of 13 September 2012 No. 893 from September 5, 2018, No. 129]. www.cvk.gov.ua. Retrieved from http://www.cvk.gov.ua/pls/acts/ShowCard?id=43898\&what=0 [in Ukrainian].

19. Proekt Zakonu Ukrayiny «Pro mistsevi vybory» pryiniatyi 14 lypnya 2015 roku No. 595-VIII [Draft Law of Ukraine «On Local Elections» from July 14 2015, No. 595-VIII]. zakon.rada.gov.ua. Retrieved from http://w1.c1.rada. gov.ua/pls/zweb2/webproc4_1?pf3511=55377 [in Ukrainian].

20. Proekt Zakonu Ukrayiny «Pro vnesennya zmin do deyakykh zakoniv Ukrayiny shchodo volevyyavlennya vybortsiv» pryiniatyi 21 sichnya 2019 roku No. 9492 [Draft Law of Ukraine «On Amendments to Certain Laws of Ukraine Regarding Election of Voters» from January 21 2019, No. 9492]. ligazakon.ua. Retrieved from http://search.ligazakon.ua/l_doc2.nsf/link1/JH7BO00A.html [in Ukrainian].

21. Protokol do Konventsiyi pro zakhyst prav lyudyny i osnovopolozhnykh svobod pryiniatyi 20 bereznya 1952 roku [Protocol to the Convention for the Protection of Human Rights and Fundamental Freedoms from March 20 1952]. zakon.rada.gov.ua. Retrieved from https://zakon.rada.gov.ua/laws/ show/994_535 [in Ukrainian].

22. Pyvovarov, S.V. (2019). YA - pereselenets' (abo zhyvu na okupovanykh terytoriyakh). Yak meni proholosuvaty na vyborakh? [I am a migrant (or live in occupied territories). How do I vote in elections?]. Retrieved from https:// thebabel.com.ua/profit/24244-ya-pereselenec-abo-zhivu-na-okupovanihteritoriyah-yak-meni-progolosuvati-na-viborah [in Ukrainian].

23. Shemshuchenko, Y.S. (1998). Yurydychna entsyklopediya [Legal Encyclopedia]. (Vols. 6). Kyyiv: Ukr. entsykl.» [in Ukrainian].

24. Stavniychuk, M.I. (1998). Vybory v Ukrayini [Elections in Ukraine]. Kyyiv: In-t derzhavy i prava im. V.M.Korets'koho [in Ukrainian].

25. Strashun, B.A. (2000). Konstitutsionnoye (gosudarstvennoye) pravo zarubezhnykh stran [Constitutional (state) law of foreign countries]. (Vols. 4). Moskva: Izdatel'stvo BEK [in Russian].

26. The Oxford English Dictionary. (n.d.). Retrieved from http://www.oed. $\mathrm{com} /$.

27. Vyborchi okruhy ta dil'nytsi v rozrizi administratyvno-terytorial'nykh odynyts' [Constituencies and polling stations by administrative units]. (n.d.). www.drv.gov.ua. Retrieved from https://www.drv.gov.ua/ords/portal/!cm_core. $\mathrm{cm}$ index?option=ext_dvk\&prejim=2 [in Ukrainian]. 
28. Zahors'kyy, V.S., Teleshun, S.O. (2011). Entsyklopediya derzhavnoho upravlinnya. Publichne vryaduvannya [Encyclopedia of Public Administration. Public Governance]. L'viv: L'vivs'kyy rehional'nyy instytut derzhavnoho upravlinnya Natsional'na akademiya derzhavnoho upravlinnya pry Prezydentovi Ukrayiny [in Ukrainian].

29. Zakon Ukrayiny Pro mistsevi vybory: pryiniatyi 14 lypnya 2015 roku No. 595-VIII [Law of Ukraine On local elections from July 14, 2015, No. 595-VIII]. zakon.rada.gov.ua. Retrieved from https://zakon.rada.gov.ua/laws/ show/595-19 [in Ukrainian].

30. Zakon Ukrayiny Pro status deputativ mistsevykh rad pryiniatyi 11 lypnya 2002 roku No. 93-IV [Law of Ukraine On the status of deputies of local councils from July 11 2002, No. 93-IV]. zakon.rada.gov.ua. Retrieved from https://zakon.rada.gov.ua/laws/show/93-15 [in Ukrainian].

31. Zakon Ukrayiny Pro zabezpechennya rivnykh prav ta mozhlyvostey zhinok i cholovikiv pryiniatyi 8 veresnya 2005 roku No. 2866-IV [Law of Ukraine On Ensuring Equal Rights and Opportunities for Women and Men from September 8, 2005, No. 2866-IV]. zakon.rada.gov.ua. Retrieved from https:// zakon.rada.gov.ua/laws/show/2866-15 [in Ukrainian].

\section{Відомості про авторів / Information about the Authors}

Шульга Анастасія Алімівна: Чорноморський національний університет імені Петра Могили: вул. 68 Десантників 10, Миколаїв, 54003, Україна

Shulga Anastasia: Petro Mohyla Black Sea National University: 68 Desantnykiv str. 10, Mykolaiv, 54003, Ukraine.

ORCID. ORG./ 0000-0002-8528-8722

\section{E-mail: ondain2009@ukr.net}

